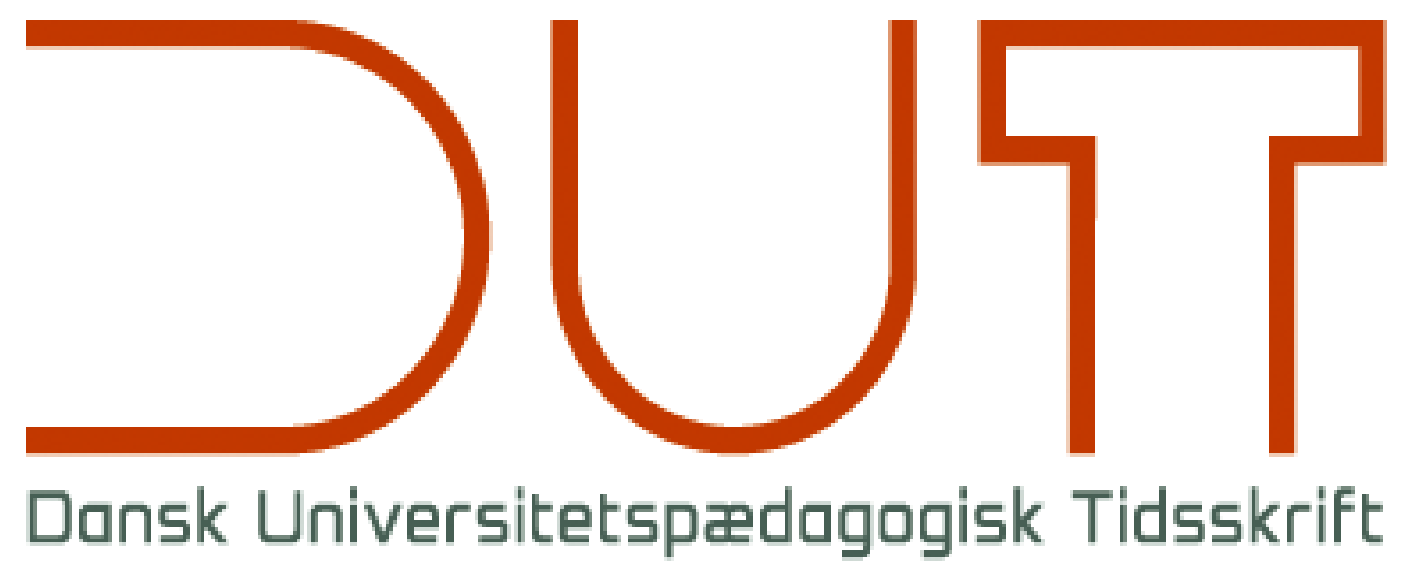

Tema

Undervisningens teknologier og teknikker

Årgang 15 nr. 28 / 2020

Titel

Faciliteret Multi-Source Feedback som pædagogisk

kompetenceudvikling - et dansk casestudie

Forfattere

Iris Maria Pedersen, Kamilla Pedersen, Diana Stentoft, Mette Krogh Christensen

Sidetal

$124-148$

Udgivet af

URL

Dansk Universitetspædagogisk Netværk, DUN

> http://dun-net.dk/

Betingelser for brug af denne artikel

(c) Copyright
Denne artikel er omfattet af ophavsretsloven, og der må citeres fra den. Følgende betingelser skal dog være opfyldt:

- Citatet skal være i overensstemmelse med "god skik"

- Der må kun citeres „i det omfang, som betinges af formålet“

- Ophavsmanden til teksten skal krediteres, og kilden skal angives ift. ovenstående bibliografiske oplysninger.

DUT og artiklens forfatter 


\title{
Faciliteret Multi-Source Feedback som pædagogisk kompetenceudvikling - et dansk casestudie
}

\author{
Iris Maria Pedersen ${ }^{\mathrm{a}, 1}$, Kamilla Pedersen ${ }^{\mathrm{b}}$, Diana Stentoft' ${ }^{c}$, Mette Krogh Christensen ${ }^{\mathrm{d}}$ \\ a,b,d Center for Sundhedsvidenskabelige Uddannelser, Aarhus Universitet \\ 'Institut for Medicin og Sundhedsteknologi, Aalborg Universitet
}

Videnskabelig artikel, fagfællebedømt

\begin{abstract}
De seneste års politiske og institutionelle fokus på kvalitetssikring i undervisningen på de videregående uddannelser har afdækket et behov for at anerkende undervisning på lige fod med forskning. Peer-review anvendes til anerkendelse af forskning, men kan en lignende metode også anvendes til anerkendelse af undervisning? Og hvad sker der i en organisationskultur, når peer-review af undervisningen introduceres som pædagogisk kompetenceudvikling? I denne artikel præsenteres resultaterne af et forskningsprojekt, der udviklede, afprøvede og undersøgte en pædagogisk kompetenceudviklingsmodel inspireret af peer-review - en Faciliteret Multi-Source Feedbackmodel (FMSF-model). I et kvalitativt interviewstudie undersøgte vi deltagernes $(n=15)$ oplevelse af FMSF-modellen og dens anvendelighed $i$ et organisatorisk læringsperspektiv. Resultaterne peger på, at FMSF-modellen kan facilitere handlingsorienteret refleksion til gavn for undervisernes pædagogiske kompetenceudvikling og understøtte en organisatorisk læringsstruktur qua dens målrettede og strukturerede feedbackformat. Modellens anvendelighed påvirkes dog af lokalt forankrede kulturelle normer og praksisser, f.eks. sparsom peer-feedback og -observation samt manglende transparens blandt deltagerne.
\end{abstract}

\section{Introduktion}

I de senere år har der været øget politisk fokus på at sikre kvalitet i undervisningen på universitetsuddannelserne. Uddannelsernes kvalitet spiller en vigtig rolle for udmøntningen af uddannelsernes værdi i samfundet og fordrer kontinuerlig udvikling af undervisernes pædagogiske kompetencer (Kobayashi, Dolin, Søborg, \& Turner, 2017). Antallet af universitetsstuderende er stadigt stigende (UFM, 2018a), og nye undervisningsformer og -teknologier tages i brug for at fremme de mange nye og forskellige studerendes læring. Selvom studerendes læring er direkte relateret til underviserens pædagogisk-didaktiske tænkning (Schneider \& Preckel, 2017; Trigwell, Prosser, \& Waterhouse, 1999), vurderer ca. halvdelen af danske universiteters undervisere, at undervisning prioriteres lavere eller meget lavere end forskning på deres universitet, og et markant flertal vurderer, at kvaliteten af deres undervisning betyder meget lidt for deres løn og karrieremuligheder (UFM, 2014, 2018a). I stillingsstrukturen for det videnskabelige personale ved universiteterne er pædagogisk supervision og opkvalificering kun obligatorisk for adjunktstillingen, og ifølge Uddannelses- og Forskningsministeriet (2018a) er incitamentet for at udvikle lektorers og professorers pædagogiske kompetencer svagt. Nu anbefaler Uddannelses- og Forskningsministeriet (2018b), at universiteterne udvikler en praksis for systematisk at anerkende god undervisning på lige fod med forskning, og

${ }^{1}$ Kontakt: irpe@cesu.au.dk 
foreslår, at der indføres ret og pligt til pædagogisk kompetenceudvikling for undervisere på alle karrieretrin.

Studenterevalueringer anvendes ofte til vurdering af undervisningens kvalitet, men metoden kritiseres af forskere for at negligere konteksten af den pædagogiske praksis (Berk, 2009; Darwin, 2017; Schuck, Gordon, \& Buchanan, 2008; Tran, 2015), at være upålidelig til bedømmelse af underviserkompetencer (Hornstein, 2017; Kobayashi, Christiansen, et al., 2017; Uttl, White, \& Gonzalez, 2017) og at have begrænset effekt på undervisernes professionelle udvikling (Palermo, 2013; Ulriksen, 2014). At udvikle og vedligeholde kvalitet i undervisningen og ruste universitetsuddannelserne til fremtiden kræver i stedet en indsats på flere niveauer (D'Andrea \& Gosling, 2005; Roseveare, 2012), fra den individuelle underviser (Schneider \& Preckel, 2017; Trigwell et al., 1999) til undervisningskulturer (Kustra, Meadows, Dawson, \& Goff, 2014; Trowler, 2008; Trowler \& Cooper, 2002; Ulriksen, 2014) og det institutionelle niveau (Cox, McIntosh, Reason, \& Terenzini, 2011; Kobayashi, Dolin, et al., 2017).

En søgning på danske universitetspædagogiske centres hjemmesider indikerer, at der i Danmark er fokus på hhv. individuel pædagogisk kompetenceudvikling og institutionelle politikker og strategier for kvalitetssikring af undervisningen. Det mellemste niveau, dvs. undervisningskulturer og mikrokulturer blandt underviserne (Mårtensson, Roxå, \& Stensaker, 2014; Roxå \& Mårtensson, 2015), synes derimod at være et overset indsatsområde. F.eks. lader kollegial peer-feedback ikke til at være så udbredt i dansk universitetspædagogisk kontekst (UFM, 2014).

I relaterede praksisfelter som postgraduat medicinsk uddannelse (Eriksen \& Malling, 2014; Mackillop, Crossley, Vivekananda-Schmidt, Wade, \& Armitage, 2011; Wood, Hassell, Whitehouse, Bullock, \& Wall, 2006) og ledelse og management (Fleenor, Smither, Atwater, Braddy, \& Sturm, 2010; Lee \& Carpenter, 2018; Nieminen, Smerek, Kotrba, \& Denison, 2013) er multi-source feedback (MSF) eller $360^{\circ}$ feedback, validerede og integrerede dele af professionelle udviklingsprogrammer. MSF har sin oprindelse i den gren af arbejds- organisationspsykologien, der drejer sig om præstationsvurdering på arbejdspladsen (Denisi \& Murphy, 2017) med særligt fokus på surveydata som grundlag for feedback til medarbejder og/eller leder (Smither, London, \& Reilly, 2005). Feedbackstrukturen i MSF er todelt; 1) først vurderer flere feedbackgiverkategorier, inklusive feedbackmodtageren selv, en feedbackmodtagers kompetencer ved at besvare en internetbaseret feedbackspørgeramme, og 2) dernæst mødes en feedbackfacilitator med feedbackmodtageren for at overbringe resultaterne af kompetencevurderingen i en feedbackrapport og facilitere en handlingsorienteret refleksion. Nyere studier viser, at MSF er velegnet pga. dets strukturerede format (Boerboom, Jaarsma, Stalmeijer, \& Dolmans, 2015) og faciliteringen (Sargeant et al., 2015), idet disse elementer fremmer feedbackmodtagerens refleksion og accept af kompetencevurderingen, som er en forudsætning for nye handlinger. De mange kilder i en MSF bidrager til en nuanceret og helhedsorienteret feedback, der sammen med en feedbackrapport giver et solidt fundament for at prioritere nye mål for ens praksisudvikling (Brown et al., 2014). Således adskiller MSF sig fra de gængse studenterevalueringer eller sporadisk peer-feedback i undervisergruppen. Det at MSF tager højde for de forskellige 'stemmer' i specifikke organisationskulturer, peger på konceptet som en velegnet tilgang til kompetenceudvikling i universitetspædagogisk sammenhæng, hvor kvalitet i universitetsundervisningen hviler på et konstruktivt samspil mellem den enkelte underviser og den undervisningskultur, som undervisningen er indlejret i (Cox et al., 2011). 
Derfor har vi $\mathrm{i}$ et forskningsprojekt udviklet og undersøgt en skalerbar kompetenceudviklingsmodel baseret på konceptet om MSF - en Faciliteret Multi-Source Feedback(FMSF) model (se figur 1) - som kan anvendes til pædagogisk kompetenceudvikling af undervisere på alle karriereniveauer i det universitetspædagogiske felt.

Figur 1. Illustration af Faciliteret Multi-Source Feedback-modellens elementer.
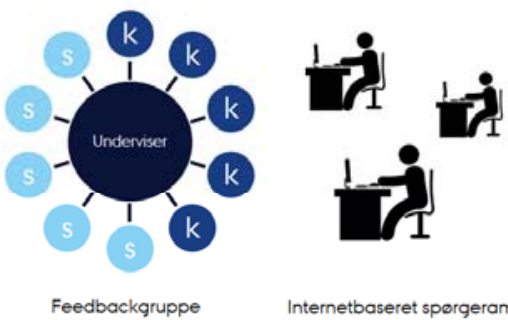

Internetbaseret spørgeramme

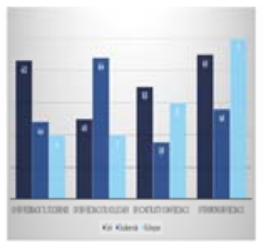

Feedbackrapport

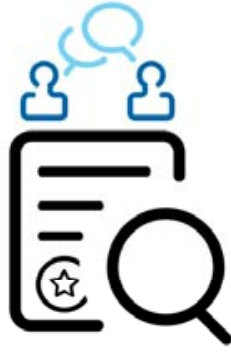

Faciliteret dialog

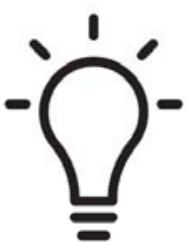

Handleplan

\section{Udforskning}

Refleksion

Handling

FMSF-modellen består af fem elementer: 1) en gruppe bestående af en underviser (feedbackmodtager) og underviserens kollegaer og studerende (feedbackgivere), 2) en feedbackspørgeramme $e^{2}$ til vurdering af feedbackmodtagers kompetencer, 3) en feedbackrapport med besvarelserne af spørgerammen, 4) en faciliteret dialog mellem en feedbackfacilitator og feedbackmodtageren og 5) en handleplan for udvalgte universitetspædagogiske indsatsområder. Se bilag 1 for uddybning af FMSF-modellens elementer.

FMSF-modellen tager udgangspunkt $\mathrm{i}$, at undervisning foregår $\mathrm{i}$ et samspil mellem mange aktører indlejret i en undervisningskultur, samtidig med at modellens feedback er orienteret mod den enkelte undervisers udvikling og handlemuligheder. FMSF-modellen adresserer således en indsats på flere niveauer:

1) På individuelt niveau tilbydes den enkelte underviser en struktureret feedback som grundlag for overvejelser over egne underviserkompetencer og for identifikation af potentielle pædagogiske udviklingsmuligheder.

2) På undervisningskulturelt niveau tilbydes grupper af universitetsundervisere en struktur for læring via faciliteret feedback, der kan fremme refleksion over egen og andres undervisning og derigennem sikre kvalitet i undervisningen.

3) På institutionelt niveau tilbydes universiteterne en forskningsbaseret og skalerbar kompetenceudviklingsmodel, som kan strukturere og fremme kontinuerlig pædagogisk kompetenceudvikling.

Idet lignende modeller endnu ikke er implementeret i en universitetspædagogisk kontekst, er det relevant at undersøge, hvordan universitetsundervisere og studerende oplever at med-

\footnotetext{
${ }^{2}$ Feedbackspørgerammen kan rekvireres ved henvendelse til forfatterne.
} 
virke til denne form for kompetenceudvikling, og hvilke faktorer der har indflydelse på FMSFmodellens anvendelighed.

I det følgende introducerer vi først undersøgelsens teoretiske forståelsesramme og dernæst forskningsspørgsmålet, der guider undersøgelsen.

\section{Teoretisk forståelsesramme}

Den teoretiske forståelsesramme for undersøgelsen ligger inden for den handlingsorienterede tradition (Brandi \& Elkjær, 2014) af organisatorisk læringsteori og er baseret på Chris Argyris' og Donald Schöns Theory of Action Perspective (1978) og Raanan Lipshitzs, Micha Poppers og Victor J. Friedmans (2002) Multifacet Model of Organizational Learning (2002). Organisatorisk læring er inden for den handlingsorienterede tradition en kontinuerlig proces, der handler om at finde og rette fejl i organisationen på baggrund af individers udforskning af aktiviteter og problematiske situationer i organisationen (Brandi \& Elkjær, 2014). Idealet er den produktive dobbelt-loop-læring, hvor selv organisationens mål, normer og værdier kan udfordres og modificeres med henblik på læring. Således relaterer denne teoretiske positionering sig til undersøgelsens problemfelt, der tegner et behov for at gentænke universiteternes tilgang til pædagogisk kompetenceudvikling og adressere kulturel forandring mod mere fælles, struktureret og kontinuerlig udvikling på alle karriereniveauer. Produktiv organisatorisk læring kræver ifølge Argyris og Schön (1978) en fri og flydende udveksling af viden mellem organisationens medlemmer og kan derfor anskues i lyset af feedbackprocesser. Teorien tilskriver sig et kognitivt læringssyn, og en læringsproces er derfor i udgangspunktet individuel, men kan blive organisatorisk, når viden deles og indlejres i organisationens handlingsmønstre (Brandi \& Elkjær, 2014). Det afgørende for, hvorvidt der er tale om organisatorisk læring, er, at ny viden fører til nye handlinger, der indlejres $i$, og dermed ændrer, organisationens handlingsmønstre til gavn for organisationen. På den måde udvikler organisationen sig hele tiden i en synergi mellem individer, der handler på vegne af organisationen og de organisatoriske handlingsmønstre, de agerer i. Ifølge Argyris og Schön (1978) hæmmes organisatorisk læring ofte af defensiv kommunikation, dvs. sløret, begrænset eller overfladisk kommunikation, der medfører at organisationen højst tilpasser sig vante rutiner med små justeringer. I et produktivt læringsperspektiv må organisationen søge at mindske defensiv kommunikation, så udveksling af viden, både indbyrdes mellem medarbejderne og mellem ledelse og medarbejdere, karakteriseres ved udforskning, åbenhed og tillid.

Lipshitz et al.'s (2002) Multifacet Model of Organizational Learning supplerer Argyris' og Schöns (1978) teoretiske fundament som en konceptuel ramme til undersøgelse af facetter af et produktivt organisatorisk læringssystem. Vi får med dette perspektiv blik for bl.a. organisatoriske læringsstrukturer, som afspejler medarbejdernes praksis for kontinuerligt at mødes, reflektere og dele viden om deres praksis på vegne af organisationen (Lipshitz et al., 2002). Lipshitz et al. (2002) introducerer begrebet om organisatoriske loeringsmekanismer for at imødekomme den modsætningsfyldte kobling af den kognitive læringsforståelse til en ikkemenneskelig entitet som organisationen:

For learning to become organizational, there must be roles, functions, and procedures that enable organizational members to systematically collect, analyze, store, disseminate, and use information relevant to their own and other members' performance. We propose that in order to learn, organizations must have nonmetaphorical analogues to the central nervous system. These analogues, which we term organizational learning mechanisms (OLMs), are observable organizational subsystems in which organization members interact for the pur- 
pose of learning. Put differently, they are antennas in which individuals can "reflect on behalf of the organization" (Argyris \& Schön, 1996). (Lipshitz et al., 2002, s. 82).

Organisatoriske læringsmekanismer installeres af ledelsen og konstitueres af medarbejdere, der udveksler og anvender viden for at forbedre deres egen og andres performance og dermed driver den produktive læring frem. Organisatoriske læringsmekanismer kan f.eks. være underviserteams, der samarbejder om de studerendes læring. Lipshitz et al. (2002) operationaliserer begrebet om defensiv kommunikation gennem deres perspektiv på kulturelle normer og psykologiske tilstande blandt medarbejderne, der kan påvirke læringens kvalitet. Med andre ord kan hensigtsmæssige læringsstrukturer hæmmes af kulturelle og psykologiske facetter af det organisatoriske læringssystem ${ }^{3}$. Kulturelle normer som transparens, integritet, udforskning og sagsorientering (Lipshitz et al., 2002) er befordrende for en åben og fri kommunikation og dermed tydelig og præcis feedback, der kan give ny, relevant indsigt og danne baggrund for nye handlemuligheder. Eftersom f.eks. transparens i et team kan være sårbar, forudsætter disse normer, at der er psykologisk sikkerhed til stede blandt medlemmerne i organisationen, ligesom ønsket om at dele viden er afhængigt af medarbejdernes organisatoriske engagement (Lipshitz et al., 2002).

\section{Forskningsspørgsmål}

FMSF-modellen kan ses som et bidrag til en organisatorisk læringsstruktur; som en måde at rammesætte en kontinuerlig udveksling af viden mellem medarbejderne med henblik på at forbedre egen og andres performance. Således kan FMSF-modellen have potentiale til at understøtte organisatorisk læring. Følgende forskningsspørgsmål guidede undersøgelsen:

Hvorledes oplever deltagere FMSF-modellens potentiale til at facilitere pcedagogisk kompetenceudvikling af universitetsundervisere, og hvilke faktorer har indflydelse på modellens anvendelighed til at understøtte organisatorisk loering?

\section{Metode}

FMSF-modellen blev pilottestet med undervisere og studerende på en uddannelse ved et større dansk universitet. Formålet med pilottesten var at afprøve de udviklede materialer og forløb med henblik på at indsamle kvalitative data, der adresserede deltagernes oplevelser med modellen og modellens anvendelighed i en universitetspædagogisk ramme. Hvorledes feedbackmodtagernes udviklede handleplaner blev effektueret, lå dog uden for denne specifikke undersøgelses fokus.

\footnotetext{
${ }^{3}$ I dette afsnit fremhæves med kursiv de seks centrale begreber transparens, integritet, udforskning, sagsorientering, psykologisk sikkerhed og organisatorisk engagement, som bliver anvendt eksplicit i analysen af resultaterne.
} 
Figur 2. Illustration af FMSF-pilotprojektets faser.

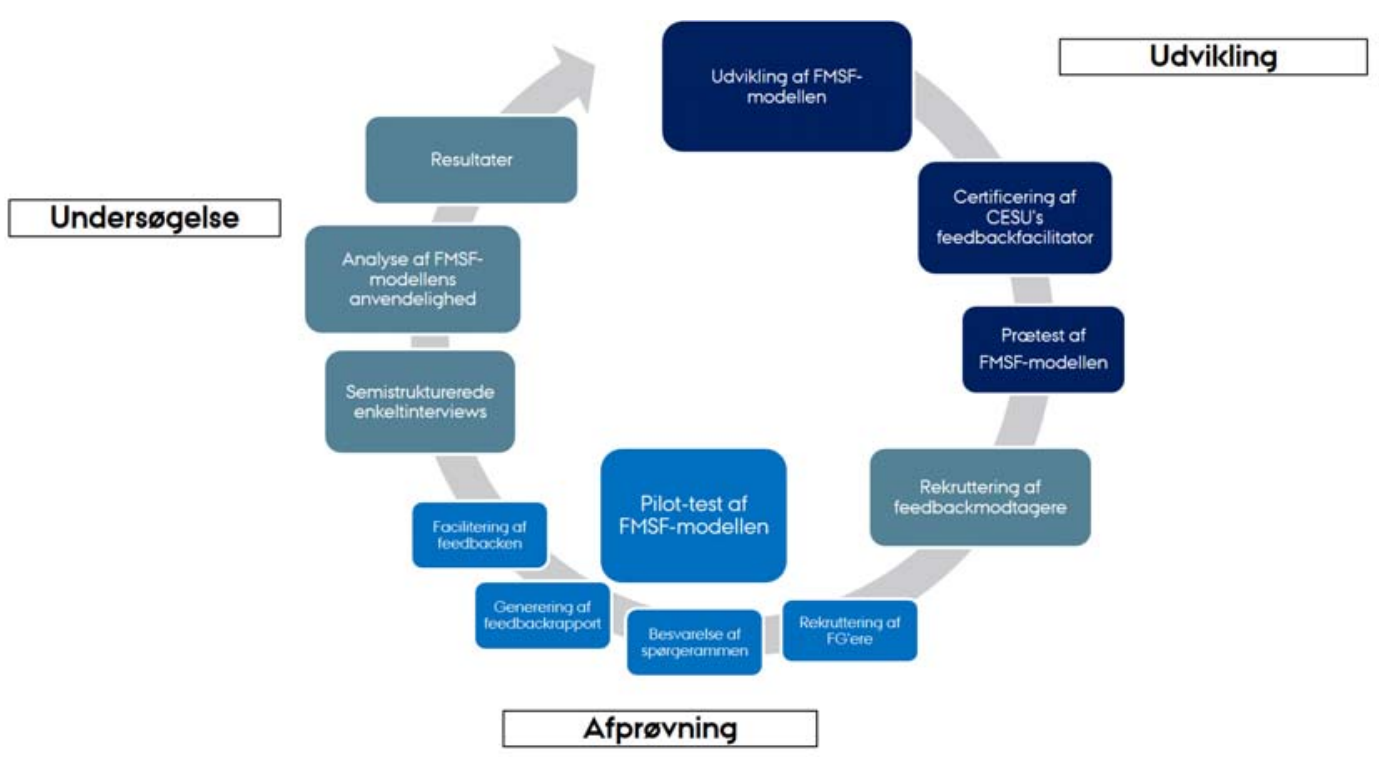

Figur 2 illustrerer FMSF-pilotprojektets faser i kronologisk rækkefølge med hhv. 1) udvikling og prætest, 2) selve pilottesten og 3) undersøgelse af deltagernes oplevelse med FMSFmodellen. I det følgende beskriver vi kort udviklingen og prætesten af FMSF-modellen. Herefter vil vi gennemgå de metodiske valg og strukturer i undersøgelsen.

Udvikling og proetest af FMSF-modellen

FMSF-modellen blev udviklet i en iterativ proces af tre af de fire forfattere til artiklen; forfatter 1, 3 og 4, der alle har en baggrund som uddannelsesforskere på videregående uddannelser.

Et konsulentfirma med erfaring i udførelse af faciliteret evaluering af postgraduate læger tjente som kritiske læsere af feedbackspørgerammens første udkast og som sparringspartnere i tilrettelæggelse af rollen som feedbackfacilitator. FMSF-modellen blev prætestet internt på forfatter 1's, 2's og 4's arbejdsplads med i alt ni deltagere; én feedbackmodtager (1 underviser), syv feedbackgivere (3 kollegaer og 4 studerende), og én feedbackfacilitator (forfatter 4). I prætesten undersøgte vi deltagernes oplevelser med FMSF-modellen ved brug af en semistruktureret interviewguide designet af forfatter 1 og kritisk gennemgået af forfatter 3 og 4. På baggrund af prætesten blev der foretaget mindre justeringer af FMSF-modellens spørgeramme og interviewguiden forud for selve pilottesten og heraf følgende undersøgelse.

Metodiske overvejelser i undersøgelsen af deltagernes oplevelser af FMSF-modellen

Undersøgelsen blev gennemført som et kvalitativt interviewstudie med fokus på deltagernes oplevelser af FMSF-modellen som universitetspædagogisk kompetenceudviklingsværktøj.

Undersøgelsens kontekst og deltagere

Konteksten for undersøgelsen var Institut Y, på Universitet Z, som var pragmatisk udvalgt og kendetegnet ved et højt pædagogisk udviklingsinitiativ. Gennem dialog med Institutleder for Institut $Y$ og Viceinstitutleder for uddannelse på Institut $Y$ indhentede vi tilladelse til at pilotteste og undersøge den udviklede FMSF-model. To erfarne universitetsundervisere meldte 
sig frivilligt som feedbackmodtagere efter en mail-invitation med information om undersøgelsens formål.

De to feedbackmodtagere rekrutterede selv deres feedbackgivere for at sikre sig en relevant feedback qua feedbackgivernes kendskab til deres praksis (Ferguson, Wakeling, \& Bowie, 2014). Feedbackgiverne blev rekrutteret i løbet af to uger blandt kollegaer og studerende på Institut $Y$ via både skriftlig og mundtlig invitation. Kollegafeedbackgiverne var hhv. lektorer og professorer, som selv varetog undervisning. Studenterfeedbackgivere var både nuværende og tidligere studerende, der kendte deres respektive underviser fra f.eks. vejledning, holdundervisning, forelæsning eller andre sammenhænge.

Forfatter 1 sendte feedbackgiverne links til besvarelse af spørgerammen. På baggrund af de udfyldte spørgerammer gennemførte feedbackfacilitatoren (forfatter 4) faciliterende dialoger med de to feedbackmodtagere af ca. én times varighed.

Alle deltagere blev inviteret til at medvirke i individuelle semistrukturerede interview for at dele deres oplevelse af FMSF-modellen. Det blev understreget, at deltagelsen i interviewet var frivillig, og at deltagerne til enhver tid kunne trække deres samtykke om deltagelse tilbage.

\section{Interviewguiden}

Med udgangspunkt i en tematisk interviewguide (se bilag 2) blev semistrukturerede enkeltinterviews med 13 feedbackgivere og to feedbackmodtagere gennemført. Fordi deltagernes oplevelse af FMSF-modellen var i fokus i undersøgelsen, valgte vi at undersøge deltagernes perspektiv med inspiration fra det fænomenologiske livsverdensinterview (Kvale \& Brinkmann, 2015). Interviewspørgsmålene blev formuleret åbent for at tilskynde righoldige og nuancerede svar og muliggøre, at interviewpersonerne selv introducerede vigtige dimensioner inden for temaerne (Kvale \& Brinkmann, 2015). Interviewguiden blev opbygget af tre temaer, inspireret af litteraturen om MSF, med overvejelse af deres bidrag til forskningsspørgsmålet. Temaerne var 1) rekruttering og rationaler for deltagelse, 2) deltagernes oplevelse af FMSF-modellen, herunder formatet og oplevelsen som hhv. feedbackmodtager og giver, og 3) feedbacksamtalen. Gennem disse temaer ønskede vi at belyse deltagernes oplevelse af FMSF-modellens anvendelighed i en universitetspædagogisk kontekst, herunder deltagernes engagement, feedbackens relevans, og betydningen af faciliteringen for oplevelsen af at opnå en brugbar feedback, som kunne omsættes til konkret handling.

\section{Dataindsamling}

Forud for interviewet modtog deltagerne information om interviewets formål og rammesætning samt etiske overvejelser, og de underskrev en informeret samtykkeformular. Alle interview blev foretaget af forfatter 1 og indledt med en briefing (Kvale \& Brinkmann, 2015). Interviewene blev tilsvarende afsluttet med en debriefing med mulighed for at afklare eventuelle spørgsmål til undersøgelsen.

\section{Analysestrategi}

Interviewene blev lydoptaget, transskriberet og nærlæst af forfatter 1 til brug for efterfølgende indholdsanalyse. Første indtryk blev noteret, og interviewtransskriptionerne blev organiseret i det kvalitative databehandlingsprogram Nvivo12. Materialet blev indledningsvist kodet åbent (Jakobsen, 2012) i et samarbejde mellem forfatter 1, 2 og 4. Dernæst fulgte en teoretisk 
læsning (Kvale \& Brinkmann, 2015) af materialet med udgangspunkt i organisatorisk læringsteori som præsenteret tidligere i denne artikel. Denne del af analysen blev foretaget i en dialog mellem alle forfattere. Således blev de induktive temaer læst og fortolket ud fra Lipshitz et al.'s (2002) perspektiv på organisationers strukturelle og kulturelle facetter og en organisationsteoretisk forståelse af kommunikation, engagement og kulturelle normer. Således tilstræbte vi en analyse, der kunne informere en diskussion af potentialer og barrierer for FMSF-modellens anvendelighed $i$ en universitetspædagogisk kontekst. Alle forfattere opnåede enighed om temaer og de citater, der blev valgt til at illustrere dem. Citaterne blev kondenseret af hensyn til læsevenlighed. Af anonymitetshensyn er proprier i citaterne erstattet af et "X".

\section{Resultater}

Samtlige deltagere i pilotprojektet påbegyndte og afsluttede besvarelsen af spørgerammen. Eftersom det var muligt at undlade at besvare spørgsmål, varierer antallet af besvarede spørgsmål i de respektive feedbackkategorier (se figur 3).

Figur 3. Procentdel af besvarede spørgsmål for hver feedbackgiverkategori.

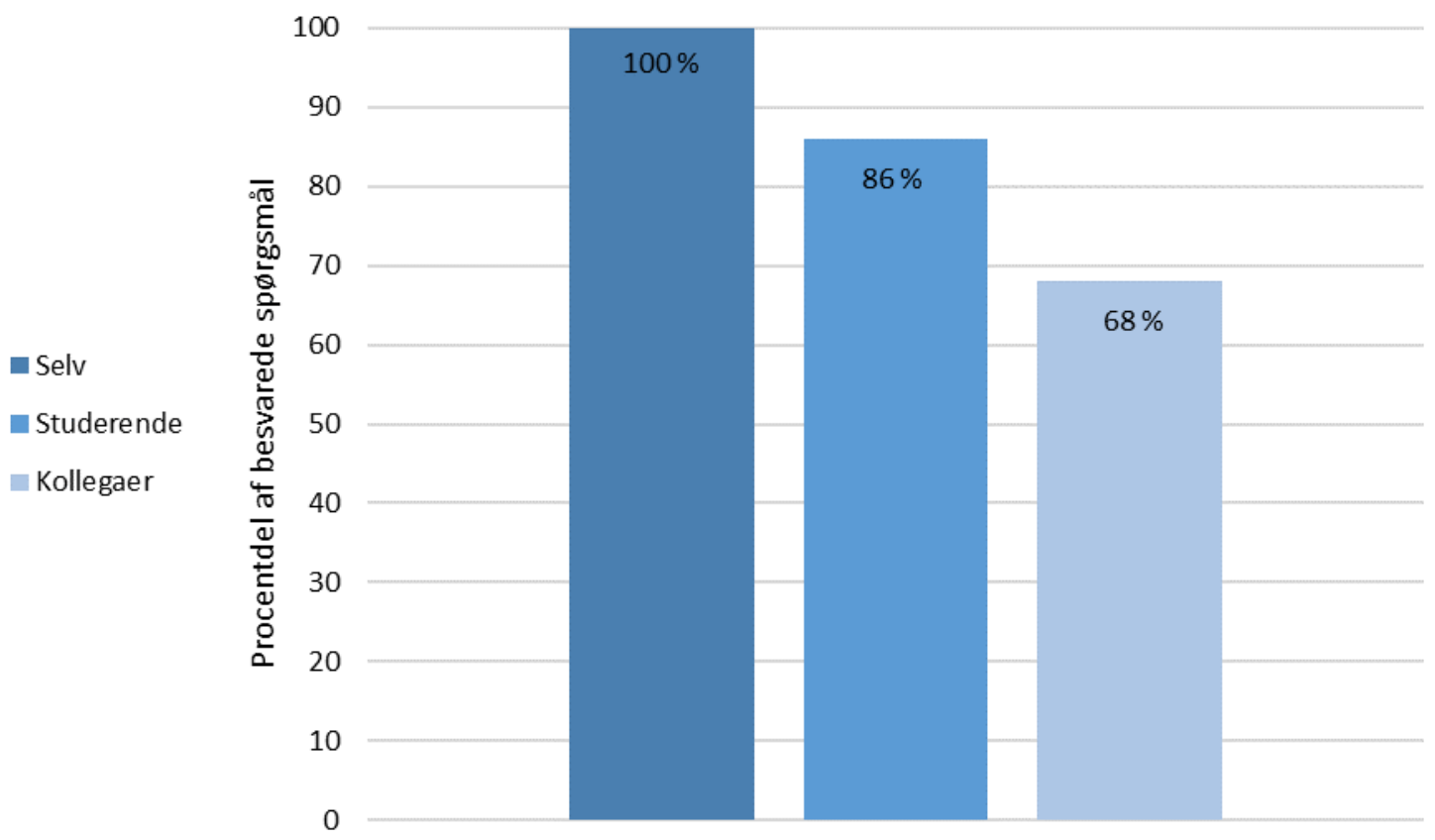

I det følgende præsenterer vi resultaterne fra analysen af de kvalitative interviews. Resultaterne omhandler deltagernes engagement i FMSF-modellen, FMSF-formatet, udfordringer med FMSF-modellen i universitetspædagogisk kontekst og deltagernes perspektiver på FMSFmodellen som bidrag til en organisatorisk læringsstruktur.

\section{Deltagernes engagement i FMSF}

I et organisatorisk læringsperspektiv er det en forudsætning for enhver læringsproces, at organisationens medlemmer engagerer sig og herigennem fremmer læring og udvikling. Alle undersøgelsens deltagere deltog frivilligt. De to feedbackmodtageres engagement var præget af nysgerrighed og søgen efter ny viden og udvikling (tabel 1, citat 1). Disse fund kendetegner en kulturel norm om udforskning (Lipshitz et al., 2002). Kollegafeedbackgiverne accep- 
terede hjælpsomt feedbackmodtagernes invitation til at give feedback og beskrev det som en selvfølge at bidrage til hinandens udvikling og kvalificere organisationens output (tabel 1, citat 2). Studerende engagerede sig ligeledes for at bidrage til den enkeltes udvikling og forbedre undervisningen generelt (tabel 1, citat 3). At kvalitetssikring af undervisningen drev deltagernes engagement i FMSF, indikerer en værdimæssig overensstemmelse mellem organisationen og dens medlemmer, der kan betegnes som organisatorisk engagement (Lipshitz et al., 2002).

Tabel 1. Citater fra informanter - Deltagernes engagement i FMSF

\begin{tabular}{lll} 
Citat nr. & Informant & Citat \\
\hline 1 & Underviser 2 & $\begin{array}{l}\text { Jeg var drevet af nysgerrighed og en villighed til altid at udvikle } \\
\text { mig med forhåbning om, at der kom nogen ting frem, som jeg } \\
\text { kan arbejde videre med. }\end{array}$ \\
\hline 2 & Kollega 1 & $\begin{array}{l}\text { Jeg synes nærmest det er et borgerligt ombud [at give feed- } \\
\text { back]. Vi vil gerne undervise så godt som muligt og alle ved, at } \\
\text { de kan udvikle sig. Det vil man naturligvis gerne støtte op om. }\end{array}$ \\
3 & Studerende 3 & $\begin{array}{l}\text { I forhold til at X skal undervise fremadrettet er det en fordel at } \\
\text { man kan bidrage til at forbedre undervisningen gennem sin } \\
\text { feedback. }\end{array}$
\end{tabular}

\section{FMSF-formatet}

Deltagerne beskrev, at omfanget af spørgerammen var passende, og at spørgsmålene kunne besvares inden for de estimerede 15 minutter. Spørgsmålene blev vurderet til at være klare og tydelige, og kompetenceområderne relevante (tabel 2, citat 1). FMSF formatet blev rost for at muliggøre en konstruktiv feedback gennem såvel feedbackgiveranonymiseringen (tabel 2 , citat 2) og formatets strukturerede og personligt målrettede karakter (tabel 2, citat 3 og 4). Ifølge feedbackgiverne gav spørgerammens kommentarfelter mulighed for at uddybe deres ratings og tilføje viden, som spørgerammen ikke frembragte. Muligheden for at undlade at besvare et eller flere spørgsmål blev beskrevet som et vigtigt element, idet feedbackgiverne hellere ville undlade at svare end at give en tilfældig og potentielt upræcis feedback (tabel 2 , citat 5 og 6 ).

Tabel 2. Citater fra informanter - FMSF-formatet

\begin{tabular}{lll}
\hline Citat nr. & Informant & Citat \\
\hline 1 & Studerende 8 & $\begin{array}{l}\text { Jeg synes kompetenceområderne er højrelevante. De rammer } \\
\text { lige ind i det X som fagperson på min uddannelse står for, og } \\
\text { de her rammer gør, at det er mere konstruktivt. }\end{array}$ \\
\hline 2 & Kollega 1 & $\begin{array}{l}\text { Her kan du give kritik uden at hive vedkommende til side. [...] } \\
\text { nu tror jeg godt, at jeg kunne sige ting til mine kollegaer, men } \\
\text { det her anonymiserede format giver mulighed for at man helt } \\
\text { sikkert kan. }\end{array}$
\end{tabular}


Studerende 3 Fordelen var at kunne give noget feedback til lige præcis X som underviser. Hidtil har vi kun givet feedback på kurset, men dette var en mulighed for at sige noget specifikt om hvad der er godt i X's undervisning og ved X som person.

4

5

6

8

Underviser 2 Det er rart at få personlig feedback hvor det går mere på mig end på kurset. Det er en god øvelse at få feedback på sig selv.

Kollega 2 Jeg havde lidt dårlig samvittighed over de spørgsmål jeg sprang over, men hvis jeg bare svarer ud fra et gæt, hvad kan det så bruges til?

Studerende 6 Principielt kunne jeg godt have givet et bud [på en kompetencevurdering] de steder hvor jeg undlod at svare, men det ville have været et useriøst bud for jeg ved det ikke.

Underviser 2

Den rapport der foreligger kan jeg bruge til noget. FMSFforløbet har givet anledning til refleksion, og har givet mig nogle handlemuligheder, som jeg glæder mig til at afprøve. de gode budskaber uden at negligere de dårlige budskaber, og viste en vej til hvordan man kan adressere dem.

Feedbackmodtagerne beskrev, at FMSF-modellen initierede en refleksiv proces og adresserede udviklingspotentiale på en meningsfuld og handlingsorienteret måde (tabel 2, citat 7). De pointerede, at den faciliterende samtale understøttede modellens handlingsorienterede sigte og formative aspekt (tabel 2, citat 8).

\section{Udfordringer ved FMSF-modellen}

\section{Sparsom peer-observation}

Både studerende og kollegaer fortalte, at de undlod at besvare nogle spørgsmål i de tilfælde, hvor de manglede viden, der kunne understøtte deres vurderinger. Den af feedbackgiverne oftest nævnte udfordring ved FMSF-modellen var manglende observation, som ifølge deltagerne indvirkede på deres evne til at besvare spørgerammen (tabel 3, citat 1 og 2).

Tabel 3. Citater fra informanter - Udfordringer ved FMSF-modellen - Sparsom peerobservation

\begin{tabular}{lll} 
Citat nr. & Informant & Citat \\
\hline 1 & Kollega 5 & $\begin{array}{l}\text { Vi ser sjældent hinanden undervise [...] du undlader at svare på } \\
\text { de items der handler om når der kommer studerende på banen, } \\
\text { fordi du ingenting ved om det. }\end{array}$ \\
\hline 2 & Studerende 8 & $\begin{array}{l}\text { Jeg ser hende jo ikke i kollegiale sammenhænge [...] Så afholder } \\
\text { man sig fra at svare på det, fordi man ikke helt ved det. }\end{array}$ \\
3 & Kollega 5 & $\begin{array}{l}\text { Engang havde vi én undervisergruppe som underviste én slags } \\
\text { studerende, og det var vi fælles om. Nu underviser vi fire slags }\end{array}$ \\
\hline
\end{tabular}


studerende og i faget som introduktionsfag og som videregående. Det betyder, at vi bliver kørt ud i hver vores satellit, og ikke rigtig ved hvad de andre laver.

$4 \quad$ Kollega 2

Ude i den kliniske hverdag ser man hinanden mere i aktion. Her har vi hver vores områder, og sidder hver for sig med lukkede døre.

Ved ikke at levere slørede eller upræcise vurderinger udviste feedbackgiverne integritet (Lipshitz et al., 2002) i deres feedback, hvilket på den ene side er et potentiale for feedbackens validitet, men også en barriere for omfanget af besvarelser. Data fra spørgerammen viste, at kollegaerne besvarede færrest spørgsmål (se figur 3), og kollegaerne beskrev, hvordan de i stigende grad oplevede at blive spredt ud og stå alene med undervisningen (tabel 3, citat 3 og 4). Organiseringen af undervisningen lader således til at positionere underviserne som "privatpraktiserende" med kun lidt eller anekdotisk kendskab til hinandens undervisning. De studerende lod til at være bedre rustet til at besvare FMSF-spørgerammen, da denne især adresserer underviserpraksis, som de i højere grad end kollegaerne observerede.

\section{Defensiv kommunikation}

At de studerende observerede undervisernes praksis, var ikke ensbetydende med, at de var eftertragtede feedbackgivere af alle undervisere. Kollegaer beskrev, at det kunne opleves som ubehageligt at "bytte roller" og lade sig bedømme af studerende (tabel 4, citat 1).

Tabel 4. Citater fra informanter - Udfordringer ved FMSF-modellen - Defensiv kommunikation

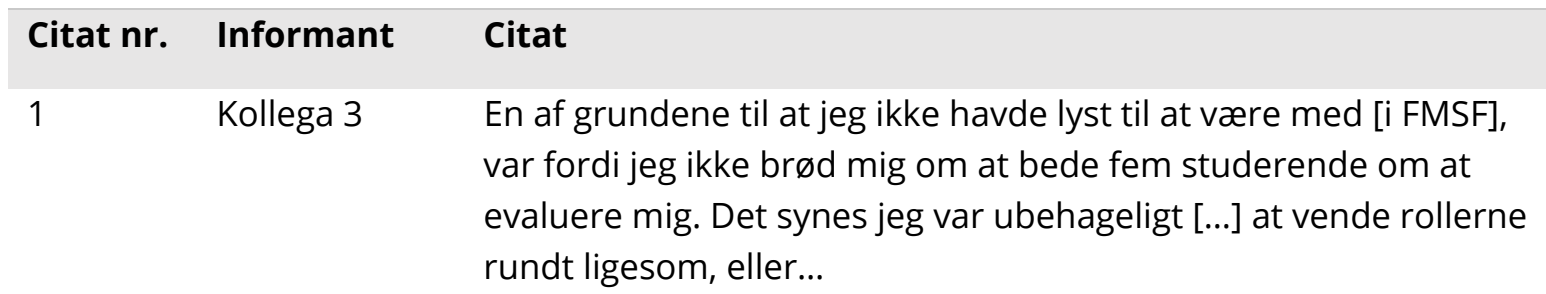
var fordi jeg ikke brød mig om at bede fem studerende om at evaluere mig. Det synes jeg var ubehageligt [...] at vende rollerne rundt ligesom, eller...

$2 \quad$ Kollega 3 Havde jeg lavet dårlige ratings havde jeg måske tænkt "shit nu laver jeg lige en "sniger" [...] En ulempe var hvis de blev stødt over det... altså man skal virkelig tænke over hvor man sætter de krydser henne.

3 Studerende 1 Jeg kunne godt se en ulempe ved at give feedback hvis det ikke havde været $X$... fordi jeg vidste godt at min feedback til $X$ ville være overvejende positiv.

4 Studerende 6 Jeg synes jo, at X er en god underviser og det betød måske også, at jeg havde mere lyst til at give feedback end hvis jeg var blevet spurgt af en dårlig underviser. jeg ikke har nogen relation til. Jeg fik rekrutteret dem som var glade for mit kursus, mens dem jeg spurgte først, takkede nej. 
Jeg tror jeg fik de bedste studerende med, og at deres feedback var mere rosende end andres havde været. Det ærgrer mig, at jeg ikke fik feedback fra de studerende som jeg mangler redskaber til at hjælpe bedre.

\section{Studerende 2}

tivt at sige, men det er jo min specialevejleder så man tænker lige om det får en indflydelse.

$7 \quad$ Underviser 1

Der er måske nogle tidspunkter hvor man er mere klar til at høre noget, som altså måske kunne være rimelig intimt eller røre dybt i ens egen selvopfattelse end andre tidspunkter.

Jeg synes det er grænseoverskridende at "åh, skal vi nu også til det? [...] skal jeg nu til at have én af mine nære kollegaer med ind, i min undervisning og se på hvad jeg laver?" [...] Jeg tror bare at man altid er bange for at der er nogen der kan komme og sætte en finger på én.

Underviser 1
De studerende ratede lidt højere end kollegaerne, og det var faktisk ikke så rart. Man vil jo gerne være velset blandt sine kollegaer. Havde fordelingen været omvendt, så tror jeg ikke det havde været ubehageligt på samme måde. Man tænker, at de studerende ikke nødvendigvis ved bedst.

Ubehaget ved at udfordre den hierarkiske opdeling mellem underviser og studerende illustrerer en mangel på sagsorientering (Lipshitz et al., 2002), dvs. at underviseren ikke forholder sig objektivt til den potentielle relevans af de studerendes viden, snarere end hierarkiske forskelle mellem feedbackgiver og -modtager. Det er således et eksempel på defensiv kommunikation. En anden udfordring for FMSF-modellens anvendelighed var, at feedbackgiverne beskrev, hvorledes feedback, som anfægtede feedbackmodtagernes pædagogiske kompetence, kunne fornærme eller såre feedbackmodtageren og derfor blev overvejet nøje (tabel 4, citat 2). Feedbackgiverne beskrev desuden, at denne risiko kunne have indflydelse på deres beslutning om at ville give feedback (tabel 4, citat 3 og 4). Underviser 2's udfordringer med at rekruttere en variation af feedbackgivere underbygger tilstedeværelsen af denne risiko (tabel 4, citat 5). Således indikerer data, at potentielle negative implikationer ved at give feedback indvirkede på, hvorvidt og hvordan feedbacken blev leveret, og illustrerer derved mangel på transparens og integritet (Lipshitz et al., 2002). Den førnævnte feedbackgiverintegritet, der tilskyndede til en så åben og præcis feedback som muligt, blev dermed udfordret af defensiv kommunikation. FMSF-modellens anonymiserende design blev desuden betvivlet af flere kollegaer og studerende, hvilket forstærkede deres overvejelser om at give kritisk feedback (tabel 4, citat 6). Også det at modtage feedback var forbundet med en vis tilbageholdenhed. Bl.a. beskrev underviserne, hvordan det at få kritisk og specifikt målrettet feedback sætter én i en sårbar position (tabel 4, citat 7). Nogle underviserkollegaer beskrev tanken om at være feedbackmodtager som intimiderende og "eksamensagtig", særligt hvis feedbacken var forbundet med observation og blev givet af en kollega på samme akademiske niveau (tabel 4, citat 8). Data indikerer desuden, at underviserens refleksion over kompetencevurderingen 
blev påvirket af, hvem der ratede lavt, og understreger at kollegaer i højere grad end studerende blev opfattet som kvalificerede bedømmere (tabel 4, citat 9).

I et organisatorisk læringsperspektiv indikerer empirien, at transparens og integritet som kulturelle normer ikke er fremtrædende i undersøgte kontekst. Det kan ses som defensiv kommunikation, når underviserkollegaerne fravælger muligheden for at udforske sin praksis gennem en FMSF, og når feedbackgiverne må overveje nøje, hvorvidt og hvordan en kritisk feedback skal overleveres. Eftersom man i undersøgte kontekst kan være "bange" for at vise, at der måske er noget, man ikke er så god til, kan det antages at den udforskende tilgang til praksis er uvant i undervisergruppen, og at der måske ikke er etableret den nødvendige grad af psykologisk sikkerhed (Lipshitz et al., 2002) og tillid til at opnå en åben og fri kommunikation i en FMSF.

\section{FMSF-modellen som bidrag til en organisatorisk loeringsstruktur}

På trods af at FMSF-modellen både var ny og uvant i undersøgte kontekst, blev den godt modtaget og opfattet som både relevant og handlingsorienteret. En kollegafeedbackgiver pointerede, at der er et stort potentiale i den refleksive dialog, hvilket medvirker til, at FMSFmodellen bliver accepteret som et bud på en pædagogisk kompetenceudviklingsmodel (tabel 5 , citat 1).

Tabel 5. Citater fra informanter - FMSF-modellen som bidrag til en organisatorisk læringsstruktur

\begin{tabular}{|c|c|c|}
\hline Citat nr. & Informant & Citat \\
\hline 1 & Kollega 2 & $\begin{array}{l}\text { Hvis man ikke er bange for at få kritik, så er der et udviklings- } \\
\text { potentiale i [FMSF] idet man får sat ord på det man gør. Jeg } \\
\text { synes tanken er god og jeg tror det bare er noget vi skal vænne } \\
\text { os til. }\end{array}$ \\
\hline 2 & Kollega 5 & $\begin{array}{l}\text { En fordel ved [FMSF] er, at det tvinger mig til at stoppe op og } \\
\text { tænke over om vi kunne opnå mere hvis vi en gang imellem } \\
\text { underviste sammen eller fulgte med i hvad hinanden gjorde. } \\
\text { Det inspirerer til at det er noget vi måske gør en gang imellem, } \\
\text { også når I ikke er på banen. }\end{array}$ \\
\hline 3 & Studerende 2 & $\begin{array}{l}\text { Fordelen [ved FMSF] er, at man reflekterer over den situation } \\
\text { man er i og over emnet, og man forholder sig måske kritisk til } \\
\text { både indhold og én selv og den man skal svare ud fra. Altså det } \\
\text { er jo konstruktivt. Man reflekterer over relationen og den gen- } \\
\text { sidighed der også er. }\end{array}$ \\
\hline
\end{tabular}

Data indikerer desuden, at FMSF-modellen gav inspiration til den kollegiale sparring i undervisergruppen og igangsatte refleksion hos kollegaer og studerende over undervisningskvalitet, relationer og potentialet i en systematisk og peer-review-baseret tilgang til pædagogisk kompetenceudvikling (tabel 5, citat 2 og 3). På denne baggrund lader FMSF-modellen til at kunne understøtte en udforskende tilgang til praksis og bidrage til en organisatorisk læringsstruktur. 


\section{Opsummering}

Resultaterne peger på, at der i undervisergruppen hverken var tradition for at observere hinandens undervisning eller vurdere hinandens underviserkompetencer. Selvom feedbackmodtagerne forholdt sig udforskende til deres underviserpraksis og udfordrede status quo, var der defensiv kommunikation at spore i undersøgte kontekst. Kollegaernes frygt for at afsløre, at der var noget, de ikke var så gode til, samt FMSF-modellens fordring om at sidestille studerende og kollegaer som feedbackgivere begrænsede deres motivation for at deltage i en FMSF. Således sås en begrænset transparens, psykologisk sikkerhed og sagsorientering blandt kollegaerne. Såvel kollegaer og studerende var tilbageholdende med at give feedback, der insinuerede inkompetence hos modtageren, og frygtede negative implikationer ved feedbacken. Således sås feedbackgiverintegritet at være udfordret af defensiv kommunikation. Dog var feedbackgivernes organisatoriske engagement $i$ at bidrage til en positiv udvikling for såvel underviseren som undervisningen befordrende for FMSF-modellens sigte, på samme måde som feedbackgivernes integritet i deres stræben efter at give en så præcis og fyldestgørende feedback som muligt. Det målrettede, strukturerede og faciliterende FMSFformat blev anset for at muliggøre en konstruktiv, relevant og handlingsorienteret feedbackproces.

\section{Diskussion}

I indledningen opridsede vi en række politiske og samfundsmæssige faktorer, der alle peger på behovet for at arbejde med målrettet kompetenceudvikling af undervisere ved de videregående uddannelser. Vi introducerede Faciliteret Multi-Source Feedback som en mulig model for kompetenceudvikling. FMSF-modellen inddrager peer-review $i$ form af feedback fra peers og andre deltagere om den enkeltes undervisning. Feedbacken indsamles systematisk og formidles og faciliteres således, at den enkelte underviser har mulighed for at opstille og arbejde med konkrete og meningsgivende målsætninger for styrkelse af egen undervisning. Undersøgelsen så på implementeringen af en FMSF-model og deltagerenes oplevelser af modellen som redskab til at understøtte professionel udvikling af erfarne universitetsunderviseres og deres praksis.

Gennem undersøgelsen så vi, at FMSF-modellen var anvendelig, eftersom den gav relevant viden om styrker og udviklingspotentialer i undervisernes undervisningskompetencer og faciliterede refleksion over underviserkompetencer hos både feedbackmodtagere og kolleger. FMSF-modellen har således potentiale til at facilitere og initiere produktiv kommunikation omkring undervisningspraksis og den enkelte undervisers ønsker eller behov for at foretage konkrete ændringer i praksis. Resultaterne af undersøgelsen er således i tråd med flere undersøgelser af MSF i postgraduat medicinsk uddannelse (Boerboom et al., 2015; Brown et al., 2014; Lombarts, Ferguson, Hollmann, Malling, \& Arah, 2016; Mackillop et al., 2011; Malling, Mortensen, Scherpbier, \& Ringsted, 2010; Saedon, Salleh, Balakrishnan, Imray, \& Saedon, 2012) og ledelse (Fleenor et al., 2010; Hattie \& Timperley, 2007; Lee \& Carpenter, 2018; Nieminen et al., 2013). FMSF-modellen afspejler også nøgleelementer i Scholarship of Teaching and Learning (Trigwell, Benjamin, \& Prosser, 2000) såsom kommunikation (Shulman, 1993), peer-review og kritisk refleksion (Schön, 1995). Vores undersøgelse viste også, at der var udfordringer forbundet med FMSF-modellen, som kalder på yderligere undersøgelse.

Nedenfor vil vi med afsæt i undersøgelsens fund pege på de områder, hvor vi mener, FMSFmodellen særligt kan bidrage, og de områder, hvor modellen kan udvikles yderligere, bl.a. 
med kritiske perspektiver på FMSF-modellens selektion og rekrutteringsdesign samt undersøgelsens metode og teori.

\section{FMSF modellens selektion og rekrutteringsdesign}

I FMSF-modellen guides feedbackgiverrekrutteringen af selvselektion, så feedbackmodtageren oplever feedbackgiverne som troværdige qua deres kendskab til feedbackmodtagerens underviserpraksis (Ferguson, Wakeling, \& Bowie, 2014). Rekrutteringsdesignet har dermed et relationelt aspekt, idet feedbackmodtageren selv opsøger og inviterer feedbackgivere, som han/hun mener har kendskab til hans/hendes praksis. Det er desuden frivilligt for feedbackgiverne at deltage.

Et aspekt ved en brugbar feedback er, at den viden, der tilvejebringes i feedbackprocessen, repræsenterer ny viden for feedbackmodtageren og derved "forstyrrer" dennes viden om sig selv (Christensen, 2016). Feedbackgivere, som man har nære relationer til, også kaldet "strong ties" (Granovetter, 1973), kan imidlertid være dårligt rustede til at give brugbar feedback, da den viden, de repræsenterer, allerede er kendt af feedbackmodtageren. "Weak ties", hvor feedbackgiver har en mere perifer relation til feedbackmodtageren, kan derimod bidrage med helt nye perspektiver og dermed understøtte refleksion. Det relationelle aspekt, der er indlejret i FMSF-modellens rekrutteringsdesign, kan derfor udfordre feedbackens potentiale til at "forstyrre" feedbackmodtageren.

I undersøgelsen skilte flere studenterfeedbackgivere sig ud som "strong ties", idet de deltog, fordi de havde et godt forhold til underviserne og forventede at kunne give overvejende positiv feedback. Selvom underviserne næppe har "stærke bånd" til deres studerende, beskrev den ene underviser det som en udfordring at rekruttere de studerende, som denne havde en perifer relation til, og hvis læring udgjorde en pædagogisk udfordring. Således tyder det på, at relationerne mellem studerende og undervisere medvirkede til en ujævn selektion af feedbackgivere, hvorfor "weak ties", altså studerende med den potentielt mest værdifulde viden, ikke blev rekrutteret i samme omfang som "strong ties".

Det relationelle aspekt af rekrutteringsdesignet kan desuden udgøre en risiko for "rater-bias" (Brown et al., 2014; Ferguson et al., 2014), der betegner risikoen for en utroværdig feedback qua et enten positivt eller negativt forhold mellem feedbackgiver og feedbackmodtager. $\mathrm{Vi}$ fandt dog ikke noget i undersøgelsen, der indikerede en upræcis eller uforholdsmæssigt positiv vurdering fra de deltagende "strong ties", men underrepræsentationen af potentielt mere negativt indstillede "weak ties" kan have givet et skævt billede af feedbackmodtagernes underviserkompetencer.

At feedbackmodtagerne selv rekrutterede deres feedbackgivere medførte, at særligt studenterfeedbackgiverne stillede spørgsmålstegn ved anonymiteten. Det kan antages, at den transparens, der er en forudsætning for at få en åben og fri udveksling af viden (Lipshitz et al., 2002), ville have haft bedre vilkår, såfremt anonymiteten havde været oplevet som reel.

På baggrund af ovenstående kan det diskuteres, om FMSF-modellens rekrutteringsdesign bør ændres således, at studenterfeedbackgiverne udvælges tilfældigt fra underviserens hold og kurser og desuden udgør en større respondentgruppe. En tilfældig udvælgelse kan bidrage til oplevelsen af anonymitet og eliminere det relationelle aspekt af rekrutteringen, hvorved risikoen for ujævn selektion og rater-bias mindskes. Således ville feedbacken kunne repræsentere et mere heterogent udsnit af studenterperspektiver på underviserens praksis og højne sandsynligheden for at bringe ny og valid viden i spil. En større respondentgruppe ville 
kunne understøtte anonymiteten i feedbackprocessen. Imidlertid kan tilfældig udvælgelse udgøre en risiko for, at feedbackgiverne har et ringe eller ensidigt kendskab til underviserens praksis og dermed et mindre pålideligt grundlag at bedømme underviseren på. Med andre ord kan de være begrænset af situationsspecificitet (Eva, Rosenfeld, Reiter, \& Norman, 2004; Vleuten, 2014), der kan påvirke validiteten. Validitet af vurderingen højnes, når den, der skal rate en person, har haft mulighed for at se personen flere gange i flere forskellige situationer over længere tid, dvs. har nogle stabile observationer, der understøtter vurderingen. Man ville altså risikere, at de studerende, der kender deres underviser både fra forelæsninger, holdundervisning og vejledningssituationer og derfor kan besvare spørgerammen i henhold til flere forskellige undervisersituationer, ikke rekrutteres. Alternativt kunne underviseren selv forme en "brutto-pulje", hvorfra de feedbackgivende studerende blev udvalgt tilfældigt. Denne tilgang ville i højere grad kunne sikre en nuanceret indsigt i underviserens undervisningspraksis og ville samtidig kunne bidrage til oplevelsen af anonymitet. Dog ville der fortsat være risiko for, at feedbackgivere med mere kritiske eller negative indspil fravælges af feedbackmodtageren. Kriterier for selektion bør under alle omstændigheder adresseres for at sikre relevant og troværdig feedback. Dette gælder også for kollegafeedbackgiverne, der var udfordret af manglende viden om feedbackmodtagernes undervisning, grundet manglende peer-observation. Et selektionskriterium for kollegafeedbackgivere kunne derfor være, at disse havde et vist antal observationer at basere deres feedback på, eller muligheden for at foretage observationer før besvarelse af spørgerammen.

\section{Kulturelle normers betydning for feedback}

Vores undersøgelse pegede på, at integritet som kulturel norm var udfordret af mangel på transparens og sagsorientering. Det påvirkede måden, hvorpå feedback blev givet, og feedbackgivere i undersøgelsen pegede på et dilemma mellem ønsket om at give præcis feedback og bekymringen for implikationerne ved at gøre det. Ifølge Lipshitz et al. (2002) forudsætter udforskning af egen praksis tilstedeværelsen af psykologisk sikkerhed og tillid, fordi: "A sense of psychological safety makes it easier to face the potentially disturbing or embarrassing outcomes of inquiry [...]" (s. 87).

Andre teorier om organisatorisk læring (Roxå \& Mårtensson, 2015; Wenger, 2000) peger også på psykologisk sikkerhed og tillid som forudsætninger for læring på arbejdspladsen og foreslår måder, hvorpå de kan adresseres. Torgny Roxå og Katarina Mårtensson (2015) bidrager med et mikrokulturelt perspektiv på, hvordan tillid og fælles opfattelse af ansvar påvirker underviseres praksis og syn på hinanden. På baggrund af vores fund kan det være hensigtsmæssigt at adressere mikrokulturer på arbejdspladsen, identificere potentielle læringsbarrierer og søge at sikre psykologisk sikkerhed forud for introduktionen af FMSF-modellen. Således vil feedbackens kvalitet og modellens anvendelighed potentielt kunne højnes til gavn for pædagogisk kompetenceudvikling.

\section{Metodiske og teoretiske refleksioner}

I undersøgelsen foretog vi en pragmatisk udvælgelse af deltagere fra en sektion på Institut Y, som var karakteriseret ved højt pædagogisk udviklingsinitiativ. Via denne metode antager undersøgelsen form af et specifikt single-casestudie, som derfor vanskeligt lader sig generalisere (Flyvbjerg, 2010). Undersøgelsen skal i stedet ses som et nedslag i det universitetspædagogiske felt med mulighed for, at andre universiteter eller organisationer, der kan genkende sig selv eller aspekter af deres organisation i undersøgelsen, kan foretage en situeret generalisering. Vi er bevidste om, at et komparativt casestudie ville have tilført en bredde til under- 
søgelsen, men singlecase-designet blev valgt ud fra pilotprojektets begrænsede tidshorisont og muligheden for at kunne gå i dybden med den indsamlede empiri.

Fokusgruppeinterview kunne have været en metode til at bringe forskellige gruppeperspektiver frem om feedbackgivernes og -modtagernes oplevelser. Vi fandt dog, at enkeltinterviewmetoden gav os en rig og varieret beskrivelse af deltagernes subjektive oplevelser med FMSFmodellen med afsæt i deres respektive kontekster, og at de åbent formulerede spørgsmål gav mulighed for, at deltagerne selv introducerede dybde til interviewene og tematikker til analysen ud fra deres individuelle perspektiv.

Blot én af artiklens forfattere stod for dataindsamling og indledende bearbejdning af datamaterialet, hvilket kan have introduceret bias til resultaterne. For at imødegå denne bias har vi dog tilstræbt transparens i fremstillingen af analysen gennem inddragelsen af fyldige citater.

Vi er bevidste om, at teoretisk læsning som analysestrategi, kan resultere i ensidige fortolkninger og temaer, hvor man kun får øje på de aspekter af fænomenerne, der kan ses gennem vores specifikke teoretiske linse. På den anden side har kodningsteknikker og forskellige teoretiske perspektiver på det samme datasæt vist sig at producere forskellige temaer, som alle har intuitiv appel og alle bidrager med udbytterige analytiske resultater (Ryan \& Bernard, 2003). Michel Foucaults begreb om governmentality kunne have bidraget med et perspektiv på magt og styring i relationen mellem kollegaer som hhv. feedbackgivere og -modtagere (Dean, 2006), mens Bronwyn Davies' og Rom Harrés positioneringsteori (1990) kunne have bidraget som perspektiv på dynamiske og omskiftelige positioner, som deltagerne tildeler sig selv og andre diskursivt, til belysning af spørgsmål om legitimitet og meningsfuldhed i feedbackprocesser. Vi mener dog, at valgte organisationsteoretiske forståelsesramme var mere anvendelig, jf. undersøgelsens forskningsspørgsmål. En forholdsregel, vi har taget for at modvirke teoretisk ensidighed, er at eksplicitere de analytiske spørgsmål, der ligger til grund for fortolkningen, og reflektere kritisk over vores egne respektive forudsætninger for at forstå forskningsemnet.

\section{Konklusion}

Det at deltage i FMSF syntes at være en modsætningsfyldt bestræbelse. På den ene side var det klart, at FMSF-modellens fordring om transparens og integritet var ny og udfordrende for den eksisterende undervisningskultur. På den anden side fandt deltagerne den strukturerede og målrettede feedback ønskværdig og viste engagement såvel som integritet i måden, hvorpå de deltog i FMSF-modellen. Opsamlende tyder vores fund på, at modellen har potentiale til at kunne understøtte pædagogisk kompetenceudvikling af erfarne universitetsundervisere og deres praksis. Resultaterne peger på, at FMSF-modellen kan facilitere handlingsorienteret refleksion til gavn for professionel udvikling i det universitetspædagogiske felt og understøtte en organisatorisk læringsstruktur qua sit målrettede og strukturerede feedbackformat. Således kan den fungere som et strukturerende element i at facilitere pædagogisk kompetenceudvikling og potentielt være katalysator for en kulturel forandring mod produktiv organisatorisk læring. Dens anvendelighed udfordres dog af lokalt forankrede kulturelle normer og praksisser, f.eks. sparsom peer-feedback og -observation, samt manglende transparens blandt deltagerne. Defensiv kommunikation ses som et tværgående tema i vores resultater, hvorfor vi foreslår, at det bliver udforsket i fremtidige studier og taget med i overvejelser $\mathrm{i}$ eventuelle iterationer af FMSF-modellen. Videre forskning kan også adressere 
rekrutteringsdesign og feedbackgiveranonymitet, handleplanernes effektuering samt anvendelse på en større og mere varieret gruppe af universitetsundervisere.

\section{Litteratur}

Argyris, C., \& Schön, D. A. (1978). Organizational Learning: A Theory of Action Perspective. California: Addison-Wesley Publishing Company.

Argyris, C., \& Schön, D. A. (1996). Organizational Learning II: Theory, methods and practice. Reading, MA: Addison-Wesley Publishing Company.

Barnard, A., Croft, W., Irons, R., Cuffe, N., Bandara, W., \& Rowntree, P. (2011). Peer partnership to enhance scholarship of teaching: A case study. Higher Education Research and Development, 30(4), 435-448.

Berk, R. A. (2009). Using the $360^{\circ}$ multisource feedback model to evaluate teaching and professionalism. Medical Teacher, 31(12), 1073-1080.

Boerboom, T. B. B., Jaarsma, D. A. D. C., Stalmeijer, R. E., \& Dolmans, D. (2015). How feedback can foster professional growth of teachers in the clinical workplace: A review of the literature. Studies in Educational Evaluation, 46, 47-52.

Brandi, U., \& Elkjær, B. (2014). Organisatorisk læring. I: Vikkelsø, S. \& Kjær, P. (Red.), Klassisk og moderne organisationsteori (s. 257-278). København: Hans Reitzels Forlag.

Brown, J. M., Lowe, K., Fillingham, J., Murphy, P. N., Bamforth, M., \& Shaw, N. J. (2014). An investigation into the use of multi-source feedback (MSF) as a work-based assessment tool. Medical Teacher, 36(11), 997-1004.

Christensen, P. H. (2016). Bedre videndeling - teoretiske og praktiske perspektiver. København: Hans Reitzels Forlag.

Cox, B. E., McIntosh, K. L., Reason, R. D., \& Terenzini, P. T. (2011). A Culture of Teaching: Policy, Perception, and Practice in Higher Education. Journal of the Association for Institutional Research, 52(8), 808-829.

D'Andrea, V.-M., \& Gosling, D. (2005). Improving Teaching And Learning In Higher Education: A Whole Institution Approach. Maidenhead Berkshire: McGraw-Hill Education.

Darwin, S. (2017). What contemporary work are student ratings actually doing in higher education? Studies in Educational Evaluation, 54, 13-21.

Davies, B., \& Harré, R. O. M. (1990). Positioning: The Discursive Production of Selves. Journal for the Theory of Social Behaviour, 20(1), 43-63.

Dean, M. (2006). Governmentality: magt og styring i det moderne samfund. Frederiksberg C.: Forlaget Sociologi.

Denisi, A. S., \& Murphy, K. R. (2017). Performance appraisal and performance management: 100 years of progress? Journal of Applied Psychology, 102(3), 421-433.

Eriksen, G. V., \& Malling, B. V. (2014). Valideret model for 360 graders feedback i den lægelige videreuddannelse er gennemførlig og acceptabel. Ugeskrift for Loeger, 2-6. 
Eva, K. W., Rosenfeld, J., Reiter, H. I., \& Norman, G. R. (2004). An admissions OSCE: The multiple mini-interview. Medical Education, 38(3), 314-326.

Ferguson, J., Wakeling, J., \& Bowie, P. (2014). Factors influencing the effectiveness of multisource feedback in improving the professional practice of medical doctors: A systematic review. BMC Medical Education, 14(1), 4-7.

Fleenor, J. W., Smither, J. W., Atwater, L. E., Braddy, P. W., \& Sturm, R. E. (2010). Self-other rating agreement in leadership: A review. The Leadership Quarterly, 21(6), 1005-1034.

Flyvbjerg, B. (2010). Fem misforståelser om casestudiet. I: Brinkmann, S. \& Tanggard, L. (Red.), Kvalitative metoder: en grundbog (s. 463-487). København: Hans Reitzels Forlag.

Granovetter, M. S. (1973). The Strength of Weak Ties. American Journal of Sociology, 78(6), $1360-1380$.

Hansen, E. J., \& Andersen, B. H. (2009). Et sociologisk vaerktøj (2. udg.) Hans Reitzels Forlag.

Hattie, J., \& Timperley, H. (2007). The Power of Feedback. Review of Educational Research, 77(1), $81-112$.

Hornstein, H. A. (2017). Student evaluations of teaching are an inadequate assessment tool for evaluating faculty performance. Cogent Education, 4(1).

Jakobsen, M. L. F. (2012). Kvalitativ analyse: kodning. I: Andersen, L.B., Hansen, K. M., \& Klemmensen, R. (Red.), Metoder i statskundskab (2. udg., s. 173-186). København: Hans Reitzels Forlag.

Kobayashi, S., Christiansen, F. V., Rump, C. Ø., Dolin, J., Jensen, T. K., \& Troelsen, R. (2017). Bedømmelse af undervisningskompetencer på baggrund af undervisningsportfolio i forbindelse med stillingsansøgninger. Vejle: DUN konference.

Kobayashi, S., Dolin, J., Søborg, A., \& Turner, J. (2017). Building Academic Staff Teaching Competencies: How Pedagogic Continuous Professional Development for Academic Staff Can Be Organised and Developed in Research-Intensive Universities. I: Stensaker, B., Bilbow, G. T., Breslow, L., \& van der Vaart, R. (Red.), Strengthening Teaching and Learning in Research Universities (s. 103-128). Cham: Springer International Publishing.

Københavns Universitet (2018). Københavns Universitets paedagogiske kompetenceprofil. Lokaliseret d. 4. oktober 2018 på: https://uddannelseskvalitet.ku.dk/udviklingsinitiativer/undervisningskompetencer/un iversitetspaedagogik/paedagogisk-kompetenceprofil/

Kustra, E., Meadows, K. N., Dawson, D., \& Goff, L. (2014). Scholarship at UWindsor Teaching Culture Indicators: Enhancing Quality Teaching.

Kvale, S., \& Brinkmann, S. (2015). Interview (3. udg.). København: Hans Reitzels Forlag.

Lee, A., \& Carpenter, N. C. (2018). Seeing eye to eye: A meta-analysis of self-other agreement of leadership. The Leadership Quarterly, 29(2), 253-275.

Lipshitz, R., Popper, M., \& Friedman, V. J. (2002). A Multifacet Model of Organizational Learning. The Journal of Applied Behavioral Science, 38(1), 78-98. 
Lombarts, K. M. J. M. H., Ferguson, A., Hollmann, M. W., Malling, B., \& Arah, O. A. (2016). Redesign of the System for Evaluation of Teaching Qualities in Anesthesiology Residency Training (SETQ Smart). Anesthesiology, 125(5), 1056-1065.

Mackillop, L. H., Crossley, J., Vivekananda-Schmidt, P., Wade, W., \& Armitage, M. (2011). A single generic multi-source feedback tool for revalidation of all UK career-grade doctors: Does one size fit all? Medical Teacher, 33(2).

Malling, B., Mortensen, L. S., Scherpbier, A. J. J., \& Ringsted, C. (2010). Educational climate seems unrelated to leadership skills of clinical consultants responsible of postgraduate medical education in clinical departments. BMC Medical Education, 10(62).

Mårtensson, K., Roxå, T., \& Stensaker, B. (2014). From quality assurance to quality practices: an investigation of strong microcultures in teaching and learning. Studies in Higher Education, 39(4), 534-545.

Nieminen, L. R. G., Smerek, R., Kotrba, L., \& Denison, D. (2013). What Does an Executive Coaching Intervention Add Beyond Facilitated Multisource Feedback? Effects on Leader Self-Ratings and Perceived Effectiveness. Human Resource Development Quarterly, 24(2), 145-176.

Palermo, J. (2013). Linking student evaluations to institutional goals: a change story. Assessment \& Evaluation in Higher Education, 38(2), 211-223.

Roseveare, D. \& Hénard, F. (2012). Fostering Quality Teaching in Higher Education: Policies and Practices, OECD. Lokaliseret d. 4. december 2019 på: https://www.oecd.org/education/imhe/QT\%20policies\%20and\%20practices.pdf

Roxå, T., \& Mårtensson, K. (2015). Microcultures and informal learning: a heuristic guiding analysis of conditions for informal learning in local higher education workplaces. International Journal for Academic Development, 20(2), 193-205.

Ryan, G. W., \& Bernard, H. R. (2003). Techniques to Identify Themes. Field Methods, 15(1), 85109.

Saedon, H., Salleh, S., Balakrishnan, A., Imray, C. H. E., \& Saedon, M. (2012). The role of feedback in improving the effectiveness of workplace based assessments: a systematic review. BMC Medical Education, 12(1), 25.

Sargeant, J., Lockyer, J., Mann, K., Holmboe, E., Silver, I., Armson, H., ... Power, M. (2015). Facilitated Reflective Performance Feedback: Developing an Evidence-and TheoryBased Model That Builds Relationship, Explores Reactions and Content, and Coaches for Performance Change (R2C2). Academic Medicine, 90(12), 1698-1706.

Schneider, M., \& Preckel, F. (2017). Variables associated with achievement in higher education: A systematic review of meta-analyses. Psychological Bulletin, 143(6), 565600.

Schön, D. A. (1995). The new scholarship requires a new epistemology. Change, 27(6).

Schuck, S., Gordon, S., \& Buchanan, J. (2008). What are we missing here? Problematising 
wisdoms on teaching quality and professionalism in higher education. Teaching in Higher Education, 13(5), 537-547.

Shulman, L. S. (1993). Teaching as community property. Change, 25(6).

Smither, J. W., London, M., \& Reilly, R. R. (2005). Does performance improve following multisource feedback? a theoretical model, meta-analysis, and review of empirical findings. Personnel Psychology, 58(1), 33-66.

Sølberg, J. (2013). Undersøgelse af egen undervisning. I: Rienecker, L., Jørgensen, P. S., Dolin, J. \& Ingerslev, G. H. (Red.), Universitetspoedagogik (1. udg., s. 423-433). Frederiksberg: Samfundslitteratur.

Tomm, K. (1992). Er hensigten at stille lineære, cirkulære, strategiske eller refleksive spørgsmål. Forum, 4.

Tran, N. D. (2015). Reconceptualisation of approaches to teaching evaluation in higher education. Issues in Educational Research, 25(1), 50-61.

Trigwell, K., Benjamin, J., \& Prosser, M. (2000). Scholarship of Teaching: A Model. Higher Education Research \& Development, 19(2), 155-168.

Trigwell, K., Prosser, M., \& Waterhouse, F. (1999). Relations between Teachers' Approaches to Teaching and Students' Approaches to Learning. Higher Education, 37(1), 57-70.

Trowler, P. (2008). Cultures and change in higher education: theories and practices. Universities into the 21st Century. Houndmills, Basingstoke, Hampshire: Palgrave Macmillan.

Trowler, P., \& Cooper, A. (2002). Teaching and Learning Regimes: Implicit theories and recurrent practices in the enhancement of teaching and learning through educational development programmes. Higher Education Research \& Development, 21(3), 221-240.

UFM (2018a). Universitetsuddannelser til fremtiden. Lokaliseret d. 4. december 2019 på: https://ufm.dk/publikationer/2018/filer/rapport-universitetsuddannelser-tilfremtiden.pdf

UFM (2018b). Bedre anerkendelse af undervisning. Lokaliseret d. 4. december 2019 på: https://ufm.dk/uddannelse/rad-naevn-og-udvalg/tidligere-rad-naevn-ogudvalg/udvalg-om-bedre-universitetsuddannelser/filer/uuu-anerkendelse-affremragende-undervisning.pdf

UFM (2014). Spørgeskemaundersøgelse blandt studerende og undervisere på de videregående uddannelser: Resultatbilag 7. Lokaliseret d. 4. december 2019 på: https://ufm.dk/publikationer/2015/nye-veje-og-hoje-mal/bilag_7.pdf

Ulriksen, L. (2014). God undervisning på de videregående uddannelser: En forskningsbaseret brugsbog (1. udg.). Frederiksberg: Frydenlund.

Uttl, B., White, C. A., \& Gonzalez, D. W. (2017). Meta-analysis of faculty's teaching effectiveness: Student evaluation of teaching ratings and student learning are not related. Studies in Educational Evaluation, 54, 22-42. 
Vleuten, C. P. M. Van Der. (2014). When I say ... context specificity. Medical Education, 48, 234235.

Von Müllen, R. (2006). Undervisningsevaluering og udvikling af underviserkompetencer. Dansk Universitetspcedagogisk Tidsskrift, 1(2), 16-21.

Wenger, E. (2000). Communities of Practice and Social Learning Systems. Organization, 7(2), 225-246.

Wood, L., Hassell, A., Whitehouse, A., Bullock, A., \& Wall, D. (2006). A literature review of multisource feedback systems within and without health services, leading to 10 tips for their successful design. Medical Teacher, 28(7). 


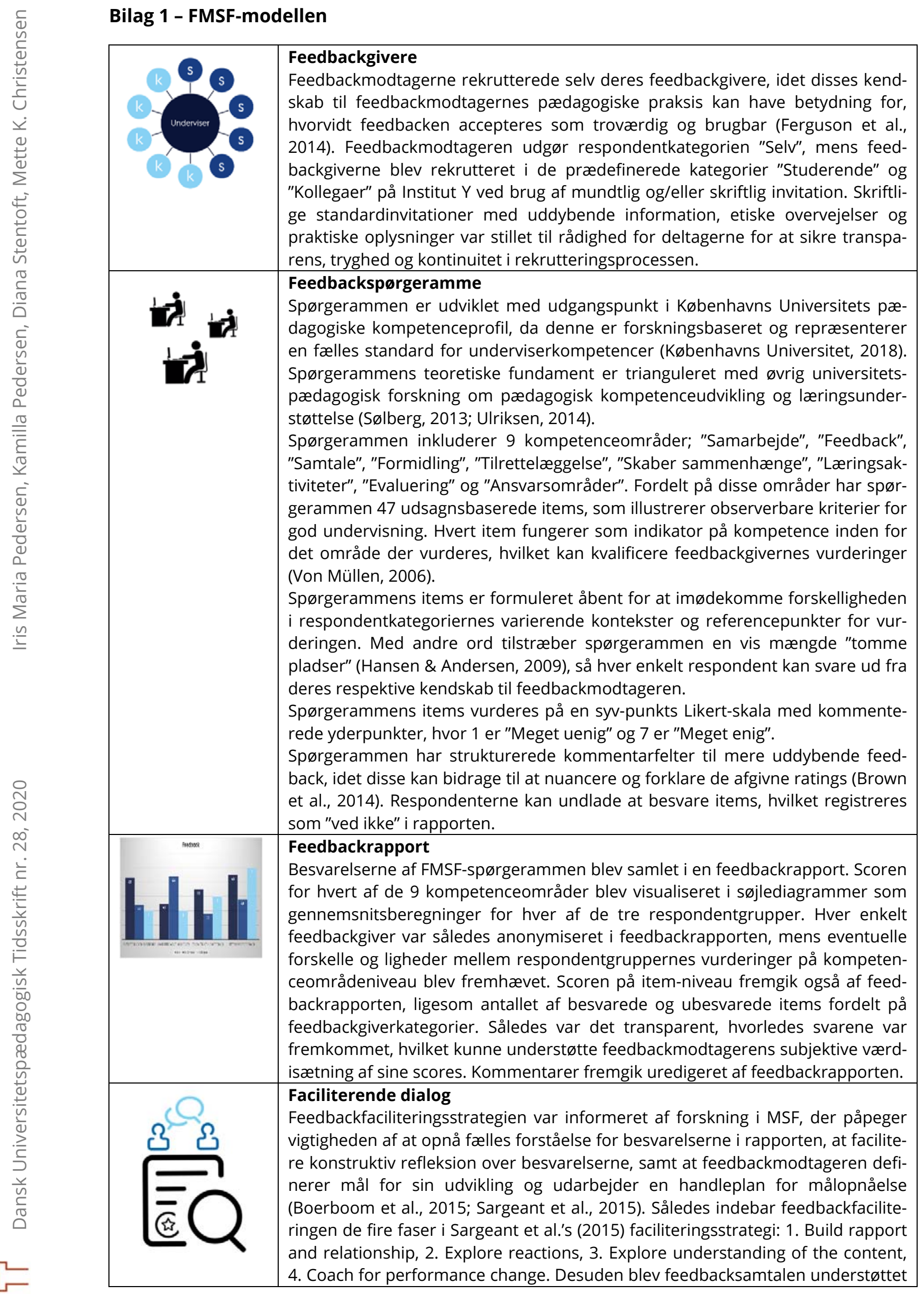




\begin{tabular}{|l|l|}
\hline & $\begin{array}{l}\text { af Karl Tomms model (1992) for facilitering af refleksivitet og nye handlemulig- } \\
\text { heder. Samtalen varede ca. 1 time. }\end{array}$ \\
\hline $\begin{array}{l}\text { Handleplan } \\
\text { Handleplanen var baseret på feedbackmodtagers refleksioner og prioriterede } \\
\text { fokusområder. Konkrete mål blev opstillet ud fra en målmatrice, hvor feed- } \\
\text { backmodtagers udviklingspotentiale blev sammenholdt med feedbackmodta- } \\
\text { gers ønsker om udvikling. I samarbejde med feedbackfacilitator udarbejdede } \\
\text { feedbackmodtager en konkret strategi for at opnå målene, herunder valg af } \\
\text { sparringskollega (Barnard et al., 2011). Dato for en opfølgende samtale blev } \\
\text { aftalt med henblik på at understøtte og fastholde feedbackmodtagers udvikling. }\end{array}$ \\
\hline
\end{tabular}

\section{Bilag 2 - Interviewguide}

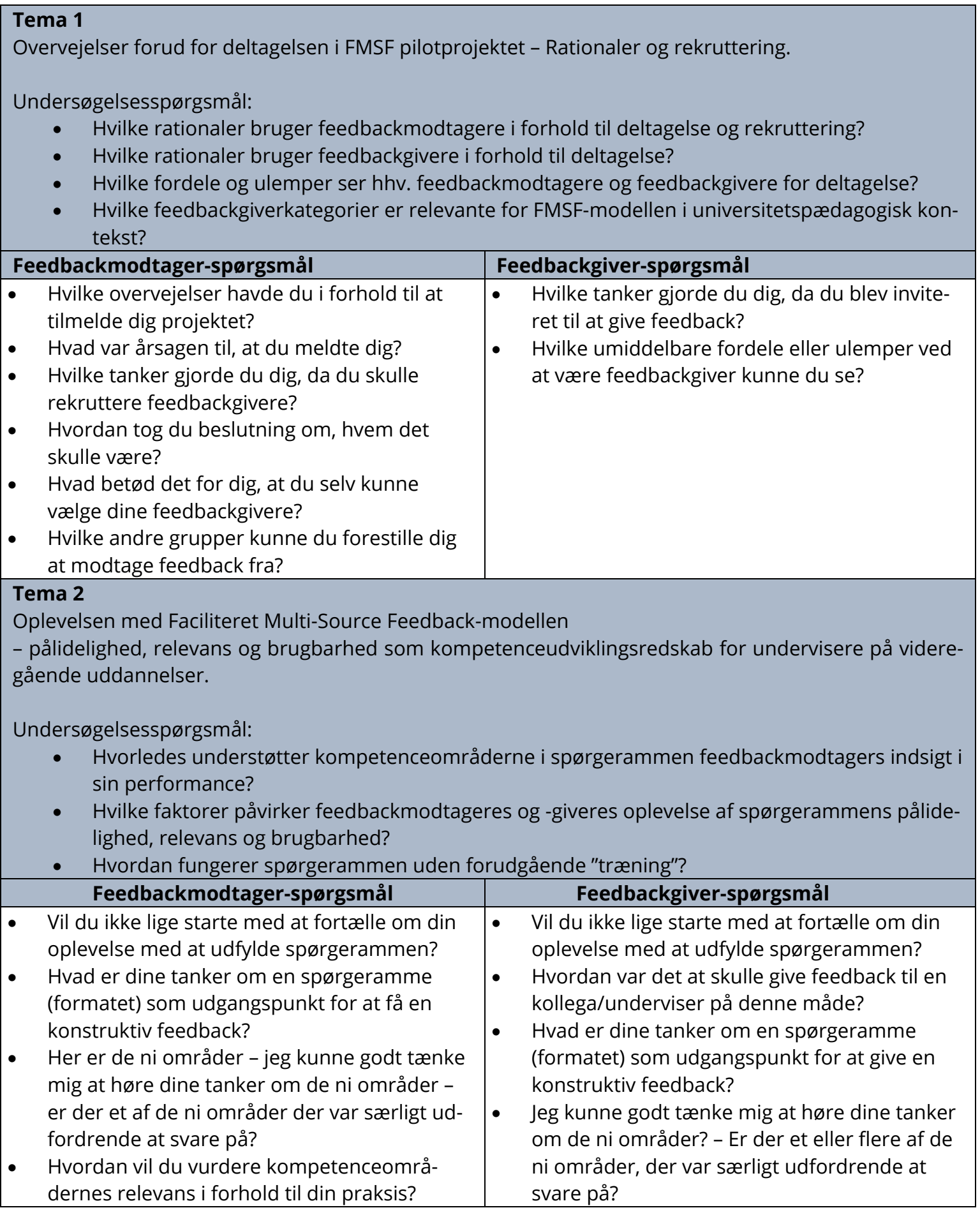




\begin{tabular}{|c|c|}
\hline & $\begin{array}{l}\text { - Følte du dig kompetent til at vurdere kompe- } \\
\text { tencerne i forhold til, hvad du ved om feed- } \\
\text { backmodtagers praksis? } \\
\text { - Hvordan vil du vurdere kompetenceområder- } \\
\text { nes relevans i forhold til universitetspædago- } \\
\text { gisk kontekst } \\
\text { - Hvad betyder det for dig, at du kan skrive } \\
\text { uddybende kommentarer til feedbackmodta- } \\
\text { ger til sidst i spørgerammen? } \\
\text { - Hvis du skulle give os et godt råd i den videre } \\
\text { udvikling af modellen, hvad ville det så være? } \\
\text { Har du andet, du vil tilføje? }\end{array}$ \\
\hline \multirow{2}{*}{\multicolumn{2}{|c|}{ 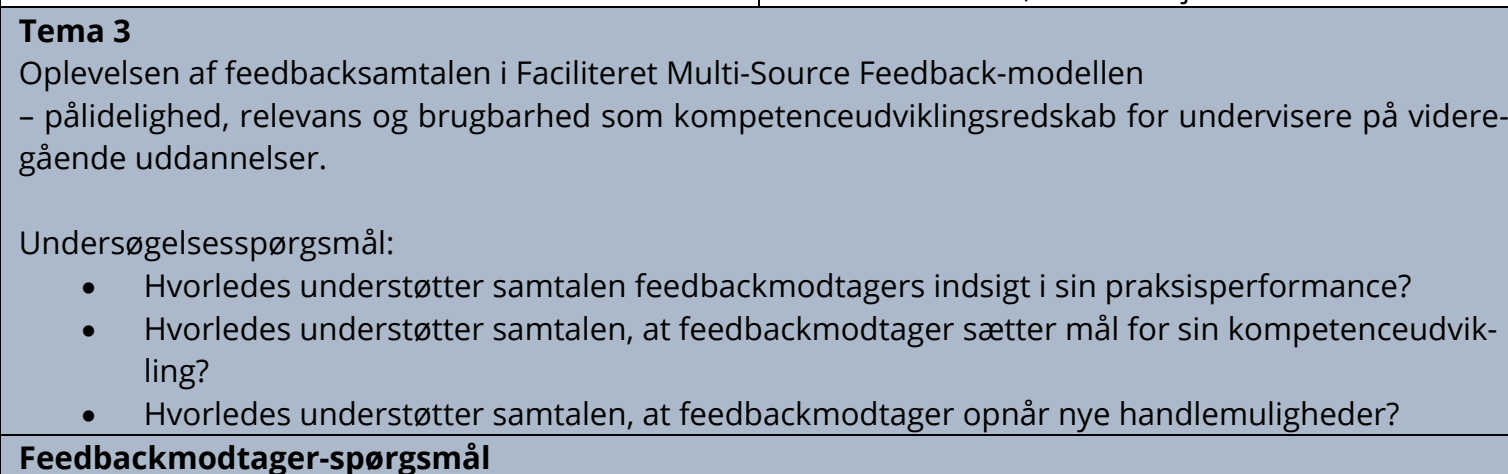 }} \\
\hline & \\
\hline \multicolumn{2}{|c|}{$\begin{array}{l}\text { - Hvordan var det at få faciliteret en feedback? } \\
\text { - } \quad \text { I samtalen så du nogle søjlediagrammer - hvordan var det at se, hvordan andre vurderer din "per- } \\
\text { - Hvad er vigtige kendetegn ved en god facilitator? } \\
\text { - Ville du have foretrukket bare at få rapporten, uden den faciliterede feedbacksamtale - hvor- } \\
\text { - } \quad \text { Vil du anborfale en faciliteret multisource feedback til andre? Hvorfor/hvorfor ikke? } \\
\text { - Hvis du skulle give os et godt råd i den videre udvikling af modellen, hvad ville det så være? Har du } \\
\text { andet, du vil tilføje? }\end{array}$} \\
\hline
\end{tabular}

